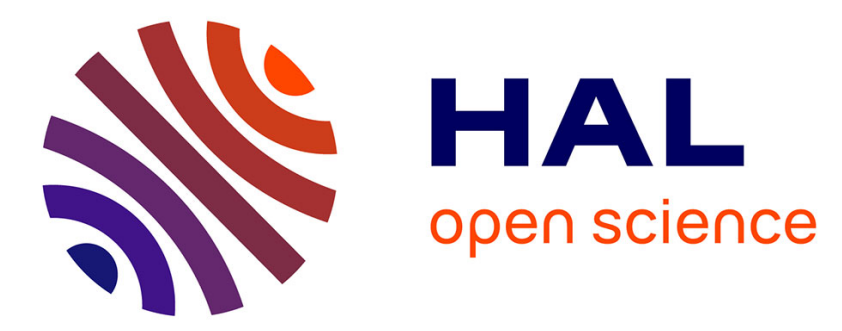

\title{
Assessing a Reclaimed Concrete Up-Cycling Scheme through Life-Cycle Analysis
}

\author{
Sylvain Guignot, Kathy Bru, Yannick Ménard, Solène Touzé
}

\section{To cite this version:}

Sylvain Guignot, Kathy Bru, Yannick Ménard, Solène Touzé. Assessing a Reclaimed Concrete UpCycling Scheme through Life-Cycle Analysis. Rewas 2013: Enabling materials resource sustainability, Mar 2013, San Antonio, United States. pp.240-260, 10.1002/9781118679401.ch26 . hal-01017132

\section{HAL Id: hal-01017132 https://hal-brgm.archives-ouvertes.fr/hal-01017132}

Submitted on 1 Jul 2014

HAL is a multi-disciplinary open access archive for the deposit and dissemination of scientific research documents, whether they are published or not. The documents may come from teaching and research institutions in France or abroad, or from public or private research centers.
L'archive ouverte pluridisciplinaire HAL, est destinée au dépôt et à la diffusion de documents scientifiques de niveau recherche, publiés ou non, émanant des établissements d'enseignement et de recherche français ou étrangers, des laboratoires publics ou privés. 


\title{
ASSESSING A RECLAIMED CONCRETE UP-CYCLING SCHEME THROUGH LIFE-CYCLE ANALYSIS
}

\author{
Sylvain Guignot ${ }^{1}$, Kathy Bru ${ }^{1}$, Solène Touzé ${ }^{1}$, Yannick Ménard ${ }^{1}$ \\ ${ }^{1}$ BRGM; 3 avenue Claude Guillemin; Orléans, 45060, France \\ Concrete, aggregate, electro-fragmentation, recycling, life-cycle analysis
}

\begin{abstract}
The present study evaluates the environmental impacts of a recycling scheme for gravels from building concretes wastes, in which the liberated aggregates are reused in structural concretes while the residual mortar fines are sent to the raw mill of a clinker kiln.

The evaluation follows a life-cycle analysis approach performed according to the ISO standard 14040, and whose scope encompasses the production of clinker through a dry kiln technology, the mining processes of the raw materials needed in the kiln, the extraction of round and crushed natural aggregates, and the crushing of concrete wastes using usual jaw crushers or pulsed-power electrical fragmentation. Insofar as possible, the inventory data are collected at the national scale of France and are recovered from the supplier of the fragmentation device, from local quarries and from an estimated mean-technology of clinker production. The choice of the impact assessment indicators is restricted to midpoints according to a problem-oriented methodology, and primarily focuses on a potential reduction in the natural resources depletion and in the $\mathrm{CO}_{2}$ emissions. The study specifically addresses the influence of $(i)$ the amount of recovered cement paste added to the kiln raw mill, and (ii) the distance of transportation modalities of concrete wastes to the crushing processes and of the recycled aggregates to construction sites. The results establish links between significant environmental gains and the various distances of transportations that intervene in the alternative processing of concrete wastes. These links will be probed more deeply in a future work.
\end{abstract}

\section{Introduction}

The current management policy of reclaimed concrete in France directs $99 \%$ of recycled coarse gravels to low added-value roadway pavement applications. In 2008, $38.2 \mathrm{Mt}$ of wastes were generated by C\&D operations, from which $15 \mathrm{Mt}$ of gravels were recovered, a figure that could reach 23 Mt provided the best available techniques for deconstruction and source separation were more widely implemented. On a technical point of view, gravels in reclaimed concretes are recovered through impact and jaw crushing, sieving stages and over-band magnetic separations of scrap metals [1]. When replacing part of the natural aggregates in concretes, recycled aggregates (RA) entail: (i) an increased drying shrinkage, (ii) decreased compressive strength, splitting tensile strength and modulus of elasticity, but (iii) no significant variations concerning frost resistance, chloride penetration and rate of carbonation [2, 3]. The loss in compressive strength is ascribed to the weaker adhesion of RA to the surrounding cement matrix in concrete, which is due to higher water absorption of the residual mortar covering the surface of the aggregates [4]. This absorption can vary between $4 \%$ and $8 \%$ of the aggregate initial mass, while only between $0.8-3.7 \%$ for NA [3]. Until recently in France, such absorption capacity banned any use of recycled aggregates in concretes [5]. 
Over the last three decades, several avenues have been explored to address this absorption issue. The first of them consisted in prewetting the recycled aggregate to the condition termed "water saturated surface dry" before concrete batching, hence preventing the attached mortar from further drawing local water [4]. However, (i) from a practical point of view, such saturated conditions are difficult to be maintained on a construction site, and (ii) prewetting the aggregates also implies a concomitant increase in cement, to ensure correct compressive strength and drying shrinkage at 28 and 182 days [6] and maintain a good concrete consistency and workability [7]. The second approach to deal with the residual mortar lie on studies having evidenced a better reliance towards local cracks propagation in concretes made from recycled aggregates, reliance which could be due to local reductions in stiffness promoted by the adhering mortar [9]. The idea is therefore to mitigate the negative effect of RA with natural aggregates, and thus, designing mixed-aggregates concretes. However, the precise quantification of the upper limit for RA addition is still difficult by its dependency to the chemical properties of the RA, to the quality of concretes from which they stem, to the kind of cement used and to the technology of concrete production. A broad common estimate for RA replacement ratio in concrete is about $30 \%$ [8]. Lastly, the third approach to manage cement paste on the RA was to design cleaning process. Several methods have been put forward [6], among which gravity concentration [10], screw grinding [11], and heating and rubbing of concrete [12]. Gravity concentration and screw grinding seem to only fit to coarse aggregates (size above 20-25 mm), with low recycling rates, about $20 \%$ and $34-45 \%$ respectively. Crushed concrete comprises $49.1 \%$ of aggregate plus adhered mortar and $43 \%$ of clean aggregates, the remaining part being composed of ceramic, bitumen and other materials [14]. The use of organic extractants has also been proposed by [13], but the environmental gains brought about by the reuse of the aggregates are counterbalanced by the use of organic extractants and the numerous washing steps associated.

On these considerations at the present time, a choice seems to be made between (i) producing cement-covered aggregates after a few basic liberation and separation processes, assess their potential use in structural concretes of various grades through standardized indicators related to their physical properties, and determine the extra amount of cement required to maintain comparable concrete properties, (ii) or ridding the aggregates of their mortar layers through more advanced, less environment-friendly separation processes to ensure their use in high-quality concrete.

Recently, our team extended the work of [17] and demonstrated that, by pulsing electrical discharges into concrete blocks, it was possible to separate coarse clean aggregates from a fine fraction having a high grade of a cement paste. Such a fraction could provide substitutes to natural limestone, clay and sand in the raw mill of a clinker kiln, while the aggregates could be up-cycled in high quality structural concretes. Both of these outlets would provide numerous advantages. First, using recycled aggregates could help to meet the forthcoming stringent legislation on the opening of new quarries of natural aggregates. Second, recycling aggregates could also save money by disposing of a cheaper aggregates supply (the pre-tax price of clean recycled aggregates ranges from 15 to 25 euros per $\mathrm{m}^{3}$ in France [16]), while avoiding paying tipping fees to landfill inert wastes (amounting to 5 euros per metric ton in France). Third, substitutes to raw mill result in reduced consumption of natural calcareous resources, coupled with reduced carbon dioxide emissions stemming from less dissociation of carbonated materials [15]. Using recycled aggregates would lessen the environmental burdens of landfilling installations, while reducing the consumption of non-renewable mineral resources. Besides it would offset local shortages of aggregates, thus reducing the need for transportation of aggregates over long distances and the various greenhouse gas emissions associated. Thus, the environmental impacts of this recycling scheme remain to be quantified. 
To the best of our knowledge, studies addressing this specific issue are rather scarce. In a LCA study addressing the production of low and high quality concretes, [18] underlined the significance of even the slight additional amount of cement required by the low quality aggregates (about $5 \%$ according to [2]), which tended to increase some environmental categories linked to respiratory effect, climate change and energy use. On the contrary, incorporating the aggregates into low quality concretes entailed no increase in cement content, and hence all environmental indicators were reduced. [19] recently reported an evaluation of a recycling scheme in which the aggregates were recovered from a heating and rubbing process and were incorporated to new concretes, while mortar was used either as a soil stabilizer or as a raw material in clinker. As long as mortar was valued, the $\mathrm{CO}_{2}$ balance became significantly negative (about $-217 \mathrm{~kg}_{\mathrm{CO} 2}$ per ton of concrete block).

Yet, these works seems to miss the fact that using RA in structural concrete rather than in roads implies that the part of gravels diverted from road to construction will have to be made up for by virgin aggregates from quarries. The overall mass balance might be relatively unaffected, but the environmental balance may be changed owing to the differences in the cleaning steps aiming at removing mortar. While part of the reclaimed concrete gravels have to meet harsher technical specifications to be used in structural concrete, the aggregates they replace will follow the reverse pattern and will not require an advanced treatment to be included in road bases. Lastly, as underlined by [2], the transportation distances of any recycling scheme dealing with heavy materials have to be heeded for, as they can set the borders between environmentally beneficial recycling schemes and the others. Therefore, various scenarios should be built up to examine the sensitivity of the environmental impacts to the transport distances of aggregates and raw materials, as well as to the way they are transported, in different concrete recycling schemes.

The present paper reports an evaluation of the environmental impacts of this alternative management of building concretes, performed according a Life Cycle Analysis methodology. For each operation considered in the processes, inputs and outputs are collected and aggregated to determine their impact on various environmental categories. These inputs/outputs cover consumptions of minerals, water or energy, as well as waste heat, air emissions, water emissions, and solid wastes to the ground. The implementation of LCA comprises four successive steps: the definition of the goal and scope of the study, the inventory of data from the considered processes, the impact assessment of these data, and the interpretation of the results [20].

\section{Goal And Scope}

\section{$\underline{\text { Goal }}$}

Current practices in concrete recycling consist in largely non-selective crushing and screening processes, which do not allow a straight separation between the clean aggregates and the cement paste. The resulting gravels are thus restricted to low-added value applications mostly in earthworks (excavation filling, roadbeds, or floor foundation).

Fragmentation of concrete rubbles by means of pulsed electrical discharges can enhance the aggregate separation from the cement paste in the concrete gravels [21], thereby broadening their range of use towards structural concretes. As an additional advantage, the hydrated cement paste mixed with sand (also termed Recycled Cement Paste or RCP) contains numerous chemical elements that could advantageously be reused to manufacture new clinkers. 
Therefore, incorporating fragmentation in the technological handling of concrete wastes result in defining a new global processing scheme for these wastes, scheme which comprises new outlets for the clean aggregates and the RCP, as well as quantitative modifications in the raw materials production for earthworks, building concrete and clinker production.

The objective of the present study is therefore to compare these two processing schemes of concrete wastes according to their respective environmental impacts. The study is thus primarily intended for aggregates suppliers, cement and concrete manufacturers, but can also be of interest to the industry of solid waste management, to several environmental organizations, and to LCA practitioners.

\section{$\underline{\text { System Boundaries And Functional Unit }}$}

A preliminary system would include the emissions and mineral resources and energy consumptions associated with: (i) the production of the raw materials needed in the clinker kiln, and (ii) the usual concrete crushing and the pulsed-power fragmentation processes.

For both processing schemes of concrete wastes, and whatever the functional unit considered processing $1 \mathrm{~kg}$ of waste building concrete or producing $1 \mathrm{~kg}$ of aggregates - a multifunctionality issue occurs due to the fact that the aggregates produced by the two systems have different outlets, either for structural concretes or for road constructions. This multi-functionality is unraveled in accordance to the recommendations of the ISO 14040 standard [22] by extending the system boundaries to include subsystems fulfilling the functions of (i) producing natural aggregates for concrete production and (ii) producing crushed aggregates for road embankments. In a processing view, the final system is therefore divided into 6 sub-units (Figure 1), and the common function of the two recycling scheme included is "processing $1 \mathrm{~kg}$ of waste concrete".

Both inputs are concretes pre-sorted from the building rubbles which contain no scrap metal that would come from steel-reinforced structures. The system is not extended beyond aggregates production to concrete manufacturing, since the produced aggregates have the same quality, hence the same use, as natural aggregates. Thus the comparison is drawn between two extreme situations - with a $0 \%$ or a $100 \%$ RA reuse in structural concretes. This deviates only slightly from current practices in France, from which almost $2 \mathrm{Mt}$ in $17 \mathrm{Mt}$ of RA are reused without further treatments. All the processes of production are followed by the cleaning operations needed for the materials to meet the quality standards of their respective function.

Second, in line with the recommendations of [23], the capital goods are included in the present LCA since part of it is intended to compare the production and the operation of alternative equipment (pulsed power fragmentation) with the continued use of existing equipment (concrete crushing). These infrastructure data are fed into the inventory table after being averaged on the totalized "functional unit" outputs of the process on its estimated lifetime. In order to be consistent, infrastructures data are also accounted for in the inventory.

Lastly, the LCA involves several transportations of heavy materials, which results in significant emissions to air, and for that reason, transports of the raw materials, of the building concrete wastes, and of the natural and recycled gravels are within the system boundaries. 
Figure 1. Boundaries of the systems considered. Up: new scheme, down: current scheme

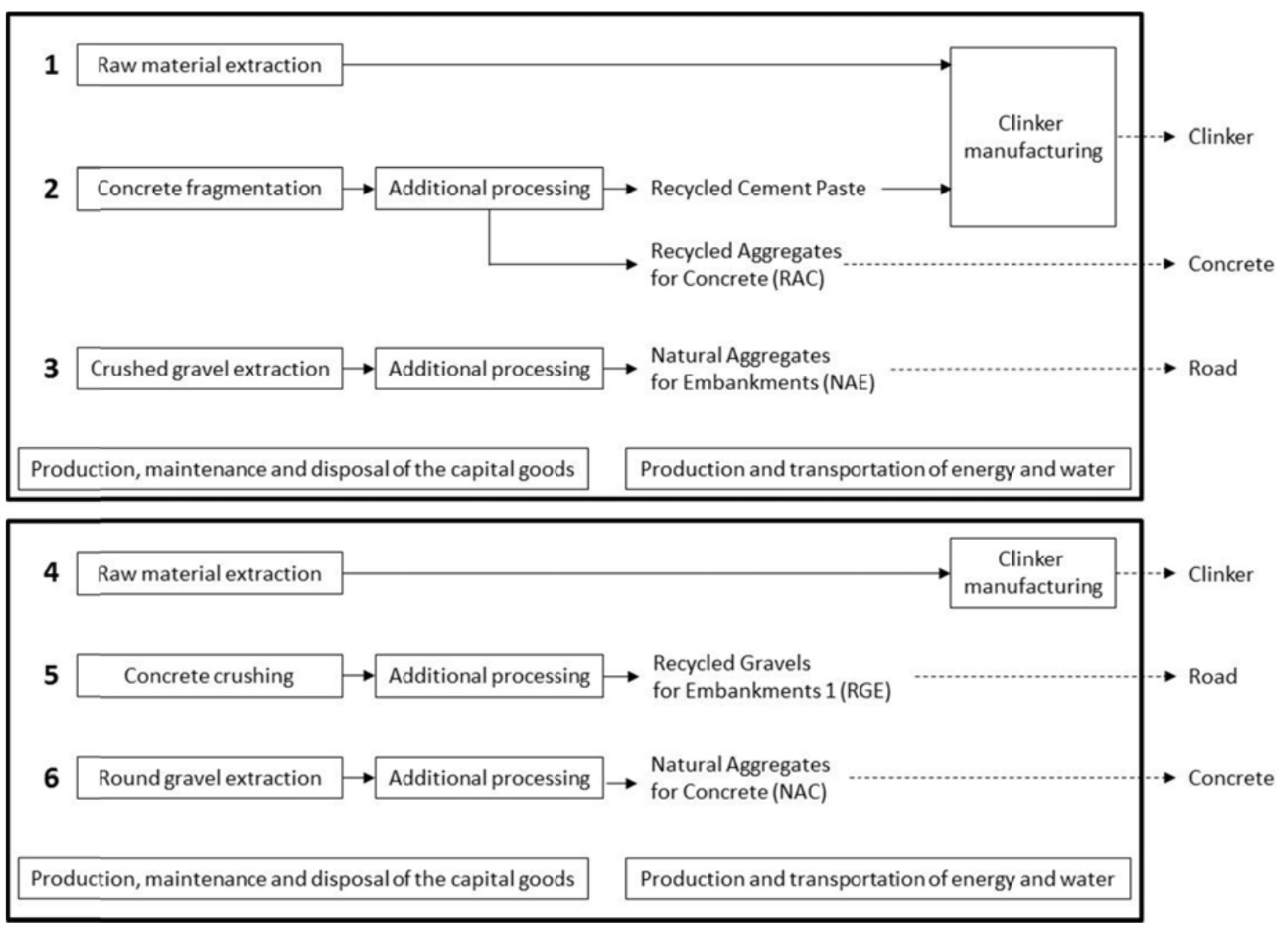

In Figure 1, it is assumed that crushed and round aggregates correspond respectively to aggregates for building concrete and road applications. The reverse case will be also implemented in the discussion part of the present LCA.

\section{Comparison Of The Usual And The New Recycling Scheme}

The relative increase in the natural aggregate consumption for embankments is accounted for by subtracting the environmental impacts associated with sub-unit (5) from that of (3). The decrease in the contribution of NA to concrete manufacturing is heeded by the subtraction of the impacts associated with (2) from the impacts of (6). The decrease in the consumption of natural resources for clinker manufacturing is obtained by subtracting the environmental impacts of (4) from (1). Let $p$ the recovery rate (on a mass basis) for aggregates in the sub-unit (2). Given that the common functional unit for both recycling schemes is $1 \mathrm{~kg}$ of concrete waste, (2) produces $\mathrm{p} \mathrm{kg}$ of aggregates and $(1-\mathrm{p}) \mathrm{kg}$ of recycled cement paste (see Table 3 ). Therefore, the environmental impacts calculated from [(3)-(5)] and [(2)-(6)] must be multiplied by $p$. Considering the recovered cement paste, calculations presented in the Inventory section enable to estimate its allowed range of content in the clinker raw feed. Let $\mathrm{P}_{\mathrm{RCP}}^{\mathrm{ck}}$ this mass proportion of recycled cement paste related to the production of $1 \mathrm{~kg}$ of clinker. The mass of clinker which can be formed from the remaining $(1-p) \mathrm{kg}$ of recovered cement paste is thus $(1-p) / \mathrm{P}_{\mathrm{RCP}}^{\mathrm{ck}}$. Therefore, the environmental impacts of $[(1)-(4)]$ must be calculated for a throughput of $(1-\mathrm{p}) / \mathrm{P}_{\mathrm{RCP}}^{\mathrm{ck}} \mathrm{kg}$. 
As a result, the environmental extra-cost (EEC ) brought by the use of the alternative process of concrete fragmentation will be obtained by applying the following formula:

$$
\mathrm{EEC}=\mathrm{p} \cdot[(3)-(5)+(2)-(6)]+(1-\mathrm{p}) / \mathrm{P}_{\mathrm{RCP}}^{\mathrm{ck}} \cdot[(1)-(4)]
$$

This data treatment provides a solution for the allocation issue arising from the concomitant production of aggregates and recycled cement paste in the concrete fragmentation process. The environmental burdens are allocated on the basis of the mass repartition of the materials since the hydrated cement paste could not be economically balanced against the aggregates.

Lastly, note that this system excludes the landfilling of non-valuable materials stemming from process (5), and thus minimizes the environmental impact of the usual recycling scheme.

\section{$\underline{\text { Impact Assessment }}$}

The environmental categories considered for the impact assessment depend on the position chosen on the impact pathway of a given substance, they may be chosen at a midpoint or at an endpoint position. As defined in [24] the mid-points indicators concern the human toxicity, the ozone layer depletion, the formation of photooxidant species, the inorganic respiratory effects, the climate change, the aquatic and terrestrial ecotoxicity and eutrophication, the acidification, the abiotic and biotic resources depletion, and the land use. These indicators are further aggregated in indicators accounting for the final environmental impacts, or endpoints, on the human health, the abiotic and biotic natural environment, the abiotic and biotic natural resources and the abiotic and biotic artificial environment. For example, sulphur dioxide causes acid rain (mid-point indicator), and damages both human health and the natural environment (end-point indicators). The farther the indicators are on the impact pathway, the greater the associated uncertainties are. In this study, priority was given to the precision of the results, and therefore the indicator point was put as close as possible to the associated emissions, following a problemoriented, rather a damage-oriented, methodology.

The environmental impact of a given process can be global or local in scale [25], and the choice is made in the present LCA to assess global effects from local inventory data, as advised by [26]. The study aims at assessing the long-term impacts of an alternative management scheme of concrete wastes on the resource availability, the ecosystem diversity, and the human health. For these reasons, the ReCiPe MidPoint method 1.06, egalitarian version, is chosen for impact assessment [27]. The alternative scheme should enable to reduce the $\mathrm{CO}_{2}$ emissions, the natural resources consumption, and the energy use. $\mathrm{CO}_{2}$ affects the human health and the ecosystem integrity through its contribution to the radiative infrared forcing of the atmosphere, therefore, climate change (CC) is a relevant indicator. Less consumption of natural aggregates can be evaluated by the impact category "natural land transformation" (NLT), and conversely, the decrease in the energy use by the category "fossil fuel depletion" (FD). In addition, and owing to the fact that the present processes can be well documented regarding their emission in SOx and NOx, the terrestrial acidity (TA) is also considered, a relevant choice according to a study dealing with the environmental impact of cement production performed by [28]. By contrast, and due to a lack of data, the various indicators related to eutrophication, ecotoxicity, water depletion and particulate matter are discarded from the impact assessment.

The four selected indicators are therefore climate change (CC), natural land transformation (NLT), fossil fuel depletion (FD) and terrestrial acidity (TA). 


\section{Data Quality}

Given that the present LCA is intended to be used in a decision-making process, the quality of technical data is crucial. A specificity of this work is that it involves the extraction and use of aggregates from earth and from building wastes. Considering that the physical properties of the natural aggregates depend on the geographical situation of the extraction site, and that the extraction process differs with the nature of aggregate, a special attention must be paid in using local rather than global averaged process data. Obviously, a precise description of every quarry procedure cannot be envisaged. But, documenting two extremes extraction process (respectively from an alluvial source or from a solid rock) allows taking into account this situation to some extent. Another consequence is that transportation from a natural mine or from a demolition site to the pulsed power or to the usual crushing process are to be precisely defined, and again, at a regional scale. Data from processes are collected on ongoing industrial processes as far as possible. Lastly, any missing inventory data is supplied by the EcoInvent 7.3.3 database.

The Life Cycle Inventory was compiled in the SimaPro software (Pré Consultants), which also performs the impact assessment using a user-selected method of calculus

\section{$\underline{\text { Choice Of Variables Assessed }}$}

The present study aims at catching the influence of the main variables defining a recycling scheme of building concrete gravels based on a straight separation of aggregates and hydrated cement paste. This separation is performed by using specific equipment based on pulsed power fragmentation. Furthermore, the recycling scheme addresses heavy materials (may it be aggregates, raw materials for clinker kiln, or concrete gravels) and consequently, the transport modalities are of uttermost significance in an environmental evaluation.

On such consideration, the variables taken into account are listed in Table 1. Their specific values are specified in the following Inventory part.

Table 1. Variables considered in the study. ${ }^{*}$ Waste Concrete Treatment Unit

\begin{tabular}{|c|c|c|}
\hline & Variables & Evaluation \\
\hline \multicolumn{2}{|c|}{ Recycled cement paste (RCP) content in clinker kiln } & Chemical analysis of RCP \\
\hline \multirow{5}{*}{$\begin{array}{l}\text { Transportation } \\
\text { distances }\end{array}$} & $\begin{array}{c}\text { Raw materials } \\
\text { local quarry } \rightarrow \text { clinker plant }\end{array}$ & \multirow{7}{*}{$\begin{array}{c}\text { Data from } \\
\text { statistics offices } \\
\text { and scientific literature }\end{array}$} \\
\hline & $\begin{array}{c}\text { Natural aggregates } \\
\text { quarry } \rightarrow \text { road construction site } \\
\text { quarry } \rightarrow \text { building construction site }\end{array}$ & \\
\hline & $\begin{array}{c}\text { Concrete gravels } \\
\text { WCTU }^{*} \rightarrow \text { road construction site }\end{array}$ & \\
\hline & $\begin{array}{c}\text { HCP : } \\
\text { WCTU } \rightarrow \text { clinker plant }\end{array}$ & \\
\hline & $\begin{array}{c}\text { Recycled aggregates } \\
\text { WCTU } \rightarrow \text { building construction site }\end{array}$ & \\
\hline \multirow{2}{*}{$\begin{array}{l}\text { Mode of } \\
\text { transportation }\end{array}$} & Hauling & \\
\hline & Shipping & \\
\hline
\end{tabular}

Life Cycle Inventory (LCI) 
Life Cycle Inventory is carried out by considering each process unit as a stand-alone system, for which the surroundings environment acts as a source of all the materials and fuels inputs to the system and as a sink for all outputs from the system. For each unit process described on Figure 1, an inventory table is established and gathers the materials and energy inputs as well as the individual emissions to the air, to natural water and to the ground.

To account for the data sensitivity to the location and the geographical scale, data are collected from local quarries operators. Furthermore, data quality was improved by contacting the pulsedpower and the jaw crusher manufacturers. Finally, most of the data are reliable with time since they come from the well-established processes of clinker manufacturing, and rock and concrete crushing.

\section{$\underline{\text { Pulsed Power Fragmentation Of Concrete }}$}

A schematic representation of a reclaimed concrete processing is shown Figure 2, along with the alternative part of process under study in the present work, and composed of the high voltage pulse power fragmentation device marketed by Selfrag (and termed Selfrag in what follows). The materials entering the Selfrag must be below $40 \mathrm{~mm}$ in size, and therefore a jaw crushing must be maintained in the global line of process. According to Figure 2, the $+40 \mathrm{~mm}$ fraction is directed towards an impact crusher to recover materials under $40 \mathrm{~mm}$ in size. Thus, the Selfrag can replace the impact crusher according to a scheme highlighted by dotted lines on the figure. Several cycles of Selfrag processing are considered to obtain the maximum amounts of hydrated cement paste on one hand and of clean aggregates on the other hand. 
Figure 2. Schematic representation of a process for recovering aggregates from concrete. Dotted lines correspond to the electrical pulsed fragmentation device

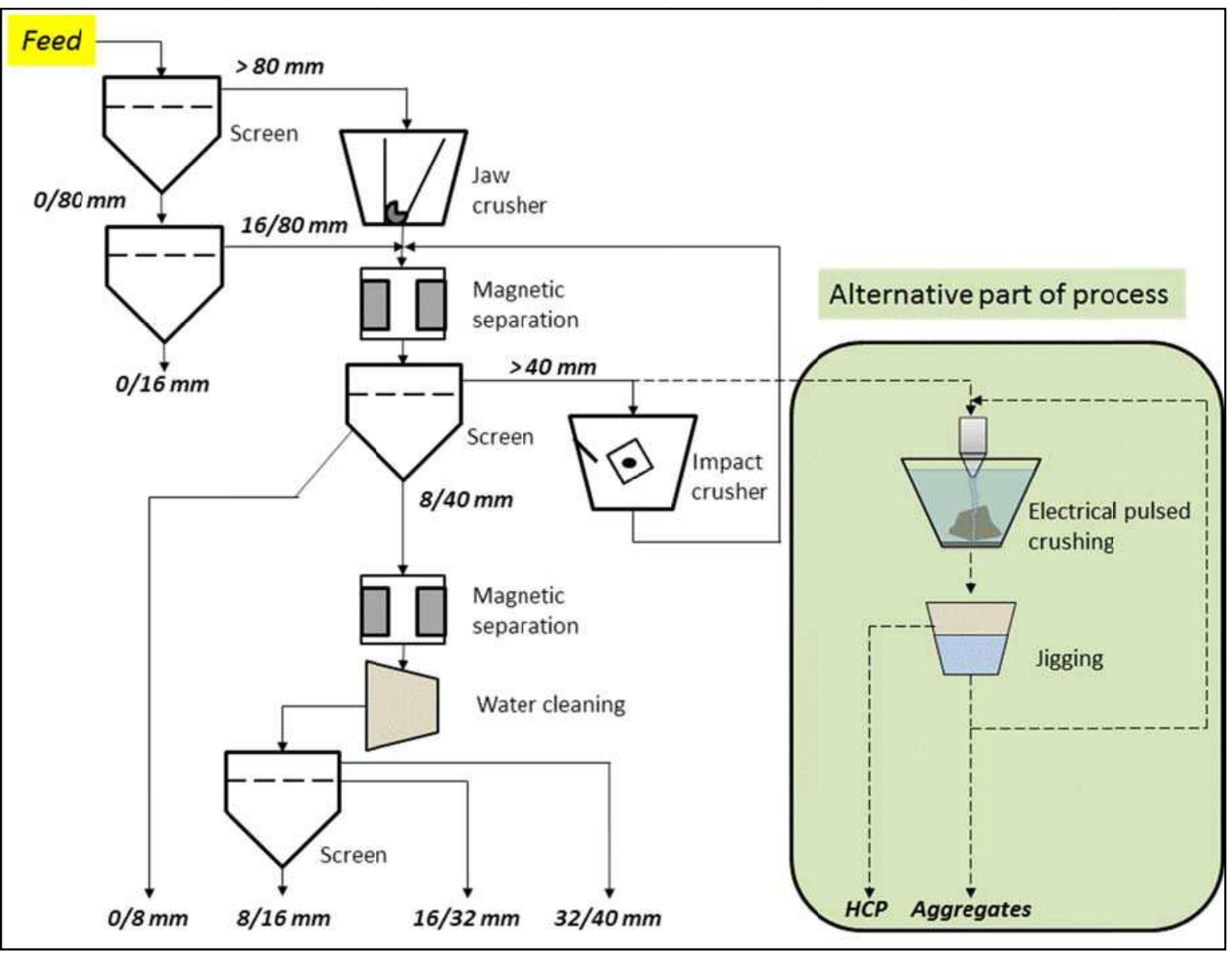

The variable parameters of the pulsed-power fragmentation are the number of pulses and the applied voltage. Experiments were carried out in our laboratory on test pieces of concrete to determine the values of these parameters to obtain the greater liberation rate of hydrated cement paste. The characteristics of the concrete specimens are summarized in were cylindrical, their length and diameter were $40 \mathrm{~mm}$ and $40 \mathrm{~mm}$ respectively, and their precise formulation is given in Table 2.

Table 2. Formulation of the concrete specimens

\begin{tabular}{|c|c|}
\hline Shape and dimension & Cylindrical, $\mathrm{h}=40 \mathrm{~mm}, \varnothing=40 \mathrm{~mm}$ \\
\hline Cement type & CEM I $52.5 \mathrm{~N}$ \\
\hline Mass ratio water/cement & 0.6 \\
\hline Mass of cement & $400 \mathrm{~kg}$ per $\mathrm{m}^{3}$ of concrete \\
\hline Mass of aggregates & $1620 \mathrm{~kg}$ per $\mathrm{m}^{3}$ of concrete \\
\hline Water & $240 \mathrm{~kg} / \mathrm{m}^{3}$ \\
\hline
\end{tabular}

According to the chemical analysis, up to $32 \%$ in weight of the initial material could be recovered in the $-2 \mathrm{~mm}$ fraction after 15 pulses of $125 \mathrm{kV}$ were applied. The process was run a second time on the $+2 \mathrm{~mm}$ fraction. The chemical contents of $\mathrm{CaO}, \mathrm{SiO}_{2}, \mathrm{Al}_{2} \mathrm{O}_{3}$ and $\mathrm{Fe}_{2} \mathrm{O}_{3}$ in the two $-2 \mathrm{~mm}$ fractions obtained enable to determine the proportions and the chemical compositions of the $-2 \mathrm{~mm}$ and the aggregates fraction leaving the process at the steady state. These values are 
summarized in Table 3, and they are used to evaluate the environmental extra-cost, see the Goal and Scope section.

Table 3. Steady-state composition of the $-2 \mathrm{~mm}$ and the aggregate fraction after pulsed-power electrical fragmentation (operating conditions are $125 \mathrm{kV}, 15$ pulses)

\begin{tabular}{|c|c|c|c|}
\hline & $(\%) w t$ & HCP content (\%)wt & Aggregates content (\%)wt \\
\hline$-2 \mathrm{~mm}$ & $47(=1-\mathrm{p})$ & 48 & 52 \\
\hline Clean aggregates & $53(=\mathrm{p})$ & 10 & 90 \\
\hline
\end{tabular}

Datas concerning the lifespan of the equipment for pulsed-power fragmentation, the chemical composition of its main parts and the total electrical consumption over its lifespan were collected from the industrial manufacturer, and added to the module defining the production of Recycled Aggregates for Concrete RAC (see below in the LCI section). For reasons of confidentiality these data are not disclosed in the present paper, but remain available upon request.

\section{Clinker Manufacturing With And Without Recycled Hydrated Cement Paste}

Global Process. Clinker is supposed to be produced in a dry process kiln with multistage preheaters and precalciners. Apart from the internal plant transportations, the main $\mathrm{CO}_{2}$ emissions come from the chemical reactions in the clinker kiln, the fuel combustion during clinker production and the electrical power consumed for raw materials and clinker grinding and milling to the desired sizes. These data fluctuates with time and from one cement plant to another, according to a seven-year monitoring of $\mathrm{SOx}, \mathrm{NOx}, \mathrm{CO}_{2}$ and clinker dust emissions performed on six cement plants by [30]. These fluctuations are related to the process stability and the efficiency of the dust filters used. Consequently, only mean values for the main emissions/consumptions can be used in the inventory, and they are documented from literature data.

Estimation Of $\mathrm{CO}_{2}$ Emissions And Minerals And Energy Consumption At The Kiln Scale. The usual feeding of the kiln is made of limestone, sand, iron ore and clay, which are the main mineral carriers of $\mathrm{Ca}, \mathrm{Si}, \mathrm{Fe}$ and $\mathrm{Al}$. Part of these elements can be supplied by the hydrated cement paste recovered from the alternative concrete fragmentation. The extent of replacement ratio in the raw feed is determined using a calculation method described in a previous communication [31] which extends the pioneering work of [32]. This calculation allows singling out the potential decrease in the $\mathrm{CO}_{2}$ emissions and in the energy consumption brought by using recycled RCP in raw material.

This methodology relates the raw mix composition (proportions of calcite, clay, iron ore and recycled $\mathrm{HCP}$ ) with the mineralogical composition of the clinker formed (mass proportions of $\mathrm{C} 3 \mathrm{~S}, \mathrm{C} 2 \mathrm{~S}, \mathrm{C} 3 \mathrm{~A}$ and $\mathrm{C} 4 \mathrm{AF}$ ), through a system of four equations determined by using Bogue equations [33] and simple mass balances between the inlet and the outlet of the kiln. The $\mathrm{CaO}$, $\mathrm{SiO}_{2}, \mathrm{Al}_{2} \mathrm{O}_{3}$ and $\mathrm{Fe}_{2} \mathrm{O}_{3}$ contents in $\mathrm{RCP}$ are determined by chemical analysis, and its mineralogical composition is assumed to be described by a mix of hydrogarnets $\mathrm{C} 3 \mathrm{AH} 6$ $\left(3 \mathrm{CaO} \cdot \mathrm{Al}_{2} \mathrm{O}_{3} \cdot 6 \mathrm{H}_{2} \mathrm{O}\right)$ and $\mathrm{C} 3 \mathrm{FH} 6\left(3 \mathrm{CaO}_{2} \mathrm{~F}_{2} \mathrm{O} 3.6 \mathrm{H}_{2} \mathrm{O}\right), \mathrm{CSH}$ silicate hydrate gel $\mathrm{C} 3 \mathrm{~S} 2 \mathrm{H} 3$ $\left(3 \mathrm{CaO} .2 \mathrm{SiO}_{2} .3 \mathrm{H}_{2} \mathrm{O}\right)$ and ettringite $\left(\mathrm{C} 3 \mathrm{~A} .3 \mathrm{CaSO}_{4} .32 \mathrm{H}_{2} \mathrm{O}\right)$, in residual amounts for mature concretes. Four specific parameters used by clinker manufacturers and related to the practical operating of the kiln are expressed from the mineralogical composition of the clinker. They are the Lea and Parker lime saturation ratio ( $\mathrm{LaP}$ ), the silica ratio (SR), the Kühn alumino-ferric module (MK) and the sum of $\mathrm{CaO}, \mathrm{SiO}_{2}, \mathrm{Al}_{2} \mathrm{O}_{3}$ and $\mathrm{Fe}_{2} \mathrm{O}_{3}$ contents in clinker (their definition can be found in [34]). These ratios are allowed to vary within precise ranges to ensure a good 
clinker workability, which therefore constrains the previous system of four equations. Using a Sequential Quadratic Programing algorithm implemented in Matlab, it is then possible to obtain the acceptable ranges for proportions of calcite, clay, iron ore and RCP in the raw feed.

Choosing a definite composition within these ranges enables to perform two calculations: $(i)$ the theoretical enthalpy at $25^{\circ} \mathrm{C}$ required for clinker reaction with $\mathrm{RCP}\left(\Delta \mathrm{H}_{\mathrm{f}}^{\mathrm{RCP}}\right)$, (ii) and the specific thermic energy consumed, which encompasses the previous enthalpy, the various heat losses around the equipment (conductive and radiative losses), and the heat losses leaving the process through the exhaust fumes, the clinker dusts, and the clinker itself. All these losses are assumed to be not affected by the change in the raw feed, and thus equal to a reference value - estimated to be $1.3 \mathrm{MJ} / \mathrm{kg}$ clinker [35]. Thus, by calculating the enthalpy for clinker reaction, the specific energy $\left(\mathrm{E}_{\mathrm{S}}^{\mathrm{RCP}}\right)$ is obtained by $\mathrm{E}_{\mathrm{S}}^{\mathrm{RCP}}=1.3+\Delta \mathrm{H}_{\mathrm{f}}^{\mathrm{RCP}}$.

Knowing the specific thermic energy and the nature of the fuel used, it is possible to calculate the amount of fossil fuel required to fulfill the heat demand of the kiln, and thereby, the amount of $\mathrm{SO}_{2}$, NOx and $\mathrm{CO}_{2}$ released during the combustion. The former value is added to the $\mathrm{CO}_{2}$ arising from the limestone dissociation, and to the emissions related to the electrical power consumptions in grinding and milling sections to obtain a global value for the $\mathrm{CO}_{2}$ emissions of the process.

Construction Of The Module In Simapro Software. The generic dry process of clinker production is chosen in the Ecoinvent database. The grounding, crushing, milling and mixing of raw materials, as well as the grinding of clinker and the collection of dusts are already allocated. The electricity used for raw meal preparation depends on the hardness of the material and it is assumed that the recycled cement paste displays the same workability as the materials it replaces. Two modules are elaborated from this generic process. The first one corresponds to a reference clinker composed of $57.9 \%$ of C3S, $21.1 \%$ of $\mathrm{C} 2 \mathrm{~S}, 12.6 \%$ of $\mathrm{C} 3 \mathrm{~A}$ and $8.4 \%$ of C4AF, starting from pure minerals (calcite, kaolinite, silica and goethite). The associated specific thermic energy $E_{S}^{0}$ is $3.14 \mathrm{MJ} / \mathrm{kg}$ of clinker, which corresponds to a mean value found in dry process kilns operated in France according to [35]. The second module corresponds to a clinker manufactured from recycled cement paste and which meets the same module values as the reference clinker. The solid combustible for both processes is a bituminous coal with a lower heating value of $35.6 \mathrm{MJ} / \mathrm{kg}$ and whose elemental composition is $88.5 \%$ of C, $5.0 \%$ of $\mathrm{H}, 4.5 \%$ of $\mathrm{O}, 1.0 \%$ of $\mathrm{S}$ and $1.0 \%$ of $\mathrm{N}$.

The internal plant transportations depend on the internal logistics of each cement plant (spaces allocated to the receipt of raw materials, to the process of production and to the silos containing the manufactured cement), which implies that only a mean value can be chosen. For the sake of simplicity, the Ecoinvent value is chosen. The external transportations are considered to be negligible owing to the fact that cement plants are often located near their respective quarry.

Table 4 summarizes the values of the data modified in the Ecoinvent module corresponding to clinker formation. As a preliminary step, two cases are considered, depending whether the LaP, SR and MK mineralogical ratio are chosen to correspond with the values for the reference clinker or with the highest decrease in the $\mathrm{CO}_{2}$ emissions.

Table 4. Data modified in the clinker module from the Ecoinvent database. Data refer to $1 \mathrm{~kg}$ of clinker

\begin{tabular}{|c|c|c|c|c|c|}
\hline & & & \multirow[b]{2}{*}{$\begin{array}{l}\text { Reference } \\
\text { clinker }\end{array}$} & \multicolumn{2}{|c|}{ Clinker with RCP } \\
\hline & & & & $\begin{array}{l}\text { Case 1: } \\
\text { Equal } \\
\text { modules }\end{array}$ & $\begin{array}{c}\text { Case 2: } \\
\text { Lowest } \mathrm{CO}_{2} \\
\text { emissions }\end{array}$ \\
\hline Raw & Limestone & $\mathrm{g} / \mathrm{kg}^{*}$ & 1217 & 1093 & 1048 \\
\hline
\end{tabular}




\begin{tabular}{|c|c|c|c|c|c|}
\hline materials & Clay/marl & $\mathrm{g} / \mathrm{kg}$ & 164.8 & 137 & 86.6 \\
\cline { 2 - 6 } & Iron Ore & $\mathrm{g} / \mathrm{kg}$ & 30.7 & 25.3 & 29.0 \\
\cline { 2 - 6 } & $\mathrm{Sand}$ & $\mathrm{g} / \mathrm{kg}$ & 149.3 & $(-)$ & $(-)$ \\
\cline { 2 - 6 } & $\mathrm{RCP}$ & $\mathrm{g} / \mathrm{kg}$ & $(-)$ & 277 & 340 \\
\hline \multirow{2}{*}{ Energy } & Hard coal & $\mathrm{g} / \mathrm{kg}$ & 88.2 & 82.3 & 78.9 \\
\cline { 2 - 6 } & Specific thermic energy & $\mathrm{kJ} / \mathrm{kg}$ & 3140 & 2895 & 2769 \\
\hline \multirow{2}{*}{ Gases } & $\mathrm{CO}_{2}$ & $\mathrm{~g} / \mathrm{kg}$ & 821.6 & 748 & 717 \\
\cline { 2 - 6 } & $\mathrm{SO}_{2}$ & $\mathrm{~g} / \mathrm{kg}$ & 1.77 & 1.65 & 1.58 \\
\hline \multirow{2}{*}{ Transport } & Raw materials & $\mathrm{kg} \cdot \mathrm{km}$ & $41^{[43]}-170^{[41]}$ & $33-137$ & $30-127$ \\
\cline { 2 - 6 } & Fuels & $\mathrm{kg} \cdot \mathrm{km}$ & $98^{[43]}-406^{[41]}$ & $79-326$ & $73-302$ \\
\hline
\end{tabular}

The specific heat energies are determined for an output of a $1 \mathrm{~kg}$ milled clinker. In the assessment of the global system, they will be weighted by the theoretical clinker mass which can be produced given the extent of substitution of the natural limestone by recycled concrete in the raw material, this extent stemming directly from the respective efficiencies of the recycling technology considered (pulsed power or impact crushing) and processed on a $1 \mathrm{~kg}$ input of waste concrete (see the Goal and Scope section).

\section{Crushing Processes Of Concrete And Natural Gravels}

Crushing processes refer to the production of aggregates from natural sources and from concretes for building concretes and for road embankments.

LCI For RAC And RGE Processes Of Production. Regarding the crushing of concrete to produce RAC, technical data are not well documented in the literature since the process is barely implemented in the industry. On an energetic point of view, the main difference between the processes of production of RAC and RGE is the replacement of the secondary impact crusher by the high voltage pulsed power device (Figure 1). According to the technical documentation from crusher suppliers, typical jaw and impact crushers need $2 \mathrm{kWh}$ and $1 \mathrm{kWh}$ per metric ton of waste concrete, as opposed to $2.5 \mathrm{kWh} / \mathrm{t}$ for the Selfrag. On this basis, the total energetic costs for a RGE and a RAC process of production are respectively 3 and $4.5 \mathrm{kWh} / \mathrm{t}$.

Regarding the various emissions and fluid consumptions of the RGE process, Table 5 summarizes inventory data for coarse recycled aggregates obtained from demolished reinforced concrete structure and crushed in a typical mobile plant [36]. These data complement the values proposed by the Ecoinvent 7.3.3 database for the module "Gravel crushed at mine", since both processes of production involve heavy crushing steps, which liberate dusts and consume fluids.

Table 5. LCI data for the recovery of recycled aggregates for embankments ${ }^{[36]}$

\begin{tabular}{|c|c|c|c|}
\hline & Consumption/emission & Unit & Value \\
\hline \multirow{4}{*}{ GHG } & Electricity & $\mathrm{kWh} / \mathrm{t}$ & $(-)$ \\
\cline { 2 - 4 } & Fuel & $\mathrm{MJ} / \mathrm{t}$ & 18.2 \\
\cline { 2 - 4 } & $\mathrm{CO}_{2}$ & $\mathrm{~g} / \mathrm{t}$ & 1695 \\
\cline { 2 - 4 } & $\mathrm{CH}_{4}$ & $\mathrm{~g} / \mathrm{t}$ & 1.59 \\
\hline \multirow{3}{*}{ Toxic gases } & $\mathrm{N}_{2} \mathrm{O}$ & $\mathrm{g} / \mathrm{t}$ & 0.67 \\
\cline { 2 - 4 } & $\mathrm{NO}_{\mathrm{x}}$ & $\mathrm{g} / \mathrm{t}$ & 19.2 \\
\cline { 2 - 4 } & $\mathrm{SO}_{\mathrm{x}}$ & $\mathrm{g} / \mathrm{t}$ & 6.7 \\
\hline \multirow{2}{*}{ Organics } & $\mathrm{CO}$ & $\mathrm{g} / \mathrm{t}$ & 4.27 \\
\hline & \multirow{2}{*}{ Non-methane $\mathrm{VOC}$} & $\mathrm{g} / \mathrm{t}$ & 0.48 \\
\hline
\end{tabular}




\begin{tabular}{|c|c|c|c|}
\hline & POP & $\mathrm{g} / \mathrm{t}$ & $2.4910^{-3}$ \\
\hline Particles & $>30 \mu \mathrm{m}$ & $\mathrm{g} / \mathrm{t}$ & 41.2 \\
\hline
\end{tabular}

The module corresponding to the RAC process is completed with the data supplied by the Selfrag Company, see above the definition of the pulsed-power fragmentation of concrete (Figure 2).

LCI For Natural Crushed Aggregates For Concrete (NAC) And Round Aggregates For Embankments (NAE). As underlined by [37], three main factors contribute to the environmental load of the processes of natural aggregates recovery: their type, accessibility and regional availability. Accessibility and regional availability impact on the transport of the recovered aggregates to their place of consumption, and have no influence on the extraction process (issues related to transport are dealt with in a following section). By contrast, the impacts are quite different according to the kind of retrieved aggregates, round or crushed. Round aggregates result from the external erosion and the exposure to weather conditions. Except for their excavation, optional transport to a processing plant, washing and grading to meet the requirements of the national standards, neither complex nor energy-costly processes are needed. This is contrasted by the blasting, transportation, crushing/milling, sieving and washing operations performed on crushed aggregates. It is assumed those crushed and round aggregates are respectively dedicated to building concretes and road applications.

Precise field data concerning these two schemes of treatment remain scarce; however, a thorough study carried out by [38] earned our attention and will be the main source of information for the present inventory. The study focuses on three sites of aggregate extraction in France, differing either by the physical characteristic of their respective aggregates or by their level of production. For the sake of simplicity, only data concerning two sites with the same production rate but a different kind of aggregates are used. Both inventories include the production of fixed assets and maintenance vehicles.

Round aggregates are assumed to be excavated from a pit by means of a wheel loader, transported to the processing unit by a conveyor belt and further processed to produce four size fractions, $0 / 4,4 / 6.3,6.3 / 10$ and 10/14. In 2005125,000 tons of aggregates have been produced with $13 \%$ of extracted materials being lost during the washing steps or being removed owing to their poor quality. $80 \%$ of the production is used in concrete batching plants or for the production of roof tiles.

Crushed aggregates are supposed to be blasted from rock mass and transported to a crushing and milling unit which falls into three successive parts, composed of a jaw and cone crushers and sieving units. The physical properties of the recovered aggregates are suitable with a use in asphalt concrete. In 2005180,000 tons of aggregates have been produced with $24 \%$ of extracted materials being non-compliant with a road use according to the French standard NF EN 12620.

The values reported on Table 6 refer to a metric ton of materials produced during the year 2005 in France. Blasting is excluded from this inventory.

Table 6. LCI data for the extraction of round and crushed aggregates. *includes fuel burned in building machine and diesel needed for internal transportations. ${ }^{* *}$ includes loading and unloading operations

\begin{tabular}{|c|l|c|c|c|}
\hline \multicolumn{2}{|l|}{} & $\begin{array}{c}\text { Round aggregates } \\
\text { NAE }\end{array}$ & $\begin{array}{c}\text { Crushed aggregates } \\
\text { NAC }\end{array}$ \\
\hline & Consumption/emission & Unit & Value & Value \\
\hline
\end{tabular}




\begin{tabular}{|c|c|c|c|c|}
\hline & Raw material & $t / t$ & 1.13 & 1.24 \\
\hline & Electricity & $\mathrm{kWh} / \mathrm{t}$ & 5.82 & 3.94 \\
\hline & Fuel & $\mathrm{MJ} / \mathrm{t}$ & $31.0^{*}$ & $20.4^{*}$ \\
\hline \multirow{3}{*}{ GHG $^{[38]}$} & $\mathrm{CO}_{2}$ & $\mathrm{~g} / \mathrm{t}$ & 2390 & 1552 \\
\hline & $\mathrm{CH}_{4}$ & $\mathrm{~g} / \mathrm{t}$ & 0.48 & 0.380 \\
\hline & $\mathrm{N}_{2} \mathrm{O}$ & $g / t$ & 3.39 & 2.66 \\
\hline \multirow{3}{*}{ Toxic gases ${ }^{[38]}$} & $\mathrm{NO}_{\mathrm{x}}$ & $g / t$ & 53.02 & 67.61 \\
\hline & $\mathrm{SO}_{2}$ & $g / t$ & 4.05 & 2.66 \\
\hline & $\mathrm{CO}$ & $\mathrm{g} / \mathrm{t}$ & 34.38 & 29.51 \\
\hline \multirow{2}{*}{ Organics $^{[38]}$} & Non-methane VOC & $\mathrm{g} / \mathrm{t}$ & 14.42 & 7.82 \\
\hline & POP & $\mathrm{g} / \mathrm{t}$ & $2.4910^{-3}$ & $1.6110^{-3}$ \\
\hline \multirow{6}{*}{ Heavy metals ${ }^{[38]}$} & $\mathrm{Cd}$ & $g / t$ & $1.9410^{-2}$ & $4.8310^{-6}$ \\
\hline & $\mathrm{Cu}$ & $g / t$ & $7.5110^{-6}$ & $8.2410^{-4}$ \\
\hline & $\mathrm{Cr}$ & $g / t$ & $1.2810^{-3}$ & $2.4310^{-5}$ \\
\hline & $\mathrm{Ni}$ & $g / t$ & $3.7510^{-5}$ & $3.4010^{-5}$ \\
\hline & Se & $g / t$ & $5.2610^{-5}$ & $4.8310^{-6}$ \\
\hline & $\mathrm{Zn}$ & $g / t$ & $7.5110^{-6}$ & $4.8510^{-4}$ \\
\hline Particles & $>30 \mu \mathrm{m}$ & $g / t$ & $30.9 * *[36]$ & $1239 * *[39]$ \\
\hline
\end{tabular}

Lastly, in each of these processes the water consumption is missing. The choice of discarding it in an inventory of aggregates extraction may seem irrelevant, particularly since the consumption strongly varies between the two extreme processes. However, choosing one the sparse data available in the literature is equally questionable since the distinction between the water withdrawn from the environment then released on one hand, and the water polluted after washing out clays from the aggregates (spent water) is often not apparent. The volume of spent water also depends on the recirculation system, which is installation-specific. As an example water consumption needed to produce 1 metric ton of aggregates in the UK ranged between 37 and 401 $\mathrm{t} / \mathrm{t}$ in 2009 [40]. Thus, giving a precise estimation for the water consumption in aggregates production lines seems unrealistic.

Regarding the specific case studied in the present work, the alternative scenario developed for the management of concrete wastes needs extra water not only for the electrical pulsed-power crushing, but also for the extra natural aggregates consumption, meaning that the various water consumptions at every stage of the global process do not balance each other. Neglecting this additional water consumption results in underestimating the depletion in abiotic resources.

\section{Transports}

Distances. Table 7 summarizes all the transports heeded in the present study. The values are found in These data represent input variables impacting the environmental balance, and their initial value are found in reports form national statistics offices and from the relevant scientific literature and by a broad estimation considering the cement plant network at a country scale. 
Table 7. Transports considered in the present study. *see Figure 2. **Waste Concrete Treatment Unit.

\begin{tabular}{|c|c|c|c|c|c|}
\hline Module* & Name & Material & Starting point & Destination & Values \\
\hline (1) (4) & $D_{1}$ & Raw Materials & Quarry & Cement plant & $41^{[44]}-170^{[41]} \mathrm{km}$ \\
\hline \multirow{2}{*}{ (3) NAE } & \multirow{2}{*}{$\mathrm{D}_{2}$} & \multirow{2}{*}{$\begin{array}{c}\text { Natural } \\
\text { aggregates }\end{array}$} & \multirow{2}{*}{ Quarry } & \multirow{2}{*}{ Road } & Road : $20^{[38]}-100^{[41]} \mathrm{km}$ \\
\hline & & & & & Boat : $100-150 \mathrm{~km}$ \\
\hline \multirow{2}{*}{ (6) NAC } & \multirow{2}{*}{$D_{3}$} & \multirow{2}{*}{$\begin{array}{c}\text { Natural } \\
\text { aggregates }\end{array}$} & \multirow{2}{*}{ Quarry } & \multirow{2}{*}{ Building } & Road : $40^{[41]}-59^{[43]} \mathrm{km}$ \\
\hline & & & & & Boat : $100-150 \mathrm{~km}$ \\
\hline $\begin{array}{l}\text { (2) RAC } \\
\text { (5) RGE }\end{array}$ & $\mathrm{D}_{4}$ & $\begin{array}{l}\text { Concrete } \\
\text { gravels }\end{array}$ & $\begin{array}{l}\text { Demolition } \\
\text { site }\end{array}$ & WCTU** & $20^{[41]}-100 \mathrm{~km}$ \\
\hline (2) RCP & $\overline{D_{5}}$ & RCP & WCTU & Cement plant & $150-200^{[46]} \mathrm{km}$ \\
\hline (5) RGE & $\mathrm{D}_{6}$ & $\begin{array}{l}\text { Concrete } \\
\text { gravels }\end{array}$ & WCTU & Road & $10-30^{[45]} \mathrm{km}$ \\
\hline (2) RAC & $D_{7}$ & $\begin{array}{l}\text { Recycled } \\
\text { aggregates }\end{array}$ & WCTU & Building & $20-100 \mathrm{~km}$ \\
\hline
\end{tabular}

\section{Raw materials}

The transport distances of raw materials (first line) show a wide range of variations, mirroring two extreme situations for supply of the quarries.

\section{Concrete gravels from demolition sites ( $R A C$ and $R G E$ )}

The waste concrete treatment unit (WCTU) handles concrete waste through usual crushing or pulsed power/microwave fragmentation: transport distances of concrete gravel are assumed to be equal whatever the treatment applied. The value can be different from zero if WCTU is not located at the demolition site, i.e. if this is not a mobile unit. According to [41], the distance between road demolition sites to landfilling installations is about $20 \mathrm{~km}$. This value will be assumed to hold for the distance to the non-mobile WCTU.

Aggregates from quarry to road site (NAE and NAC)

INSEE (the French National Statistics Office) gives an estimate for the mean transportation distance of raw materials in 2003 of $35 \mathrm{~km}$ [42]. This distance has been inching up over the last decades, an evolution mainly accounted for by several closings of quarries on environmental grounds and not compensated by the matching openings. For virgin round gravels, [38] states that the distance between the extraction and the production site is less than $2 \mathrm{~km}$, and that the graded aggregates are not sent over distances above $20 \mathrm{~km}$ to road construction/resurfacing sites. This figure falls short of the distances - between 75 to $100 \mathrm{~km}$ - considered by [41]. This discrepancy illustrates the need to precise the geographical scope heeded, as [38] refers to one specific quarry while [41] provide an averaged value. However it is important to stretch that none of this figure is closer to the truth than the other, since both suffers from a lack of representativeness respectively caused by a too small and a too large scale considered. Consequently and for the sake of completeness, both values will be taken into account in the simulation. Regarding natural aggregates supply for structural concretes, [43] gives a precise value of $59 \mathrm{~km}$, valid in the administrative area surrounding Paris.

Aggregates from various origins to road site (RGE)

Recycled aggregates travel $30 \mathrm{~km}$ on average to reach the site of road construction, according to the French Union of Carriers and Building Products Industries in a recent publication [45]. No other reliable figure was found in literature concerning local data.

Aggregates from demolition sites to building construction centers (RAC)

The corresponding distances of the aggregates whereabouts remain without a precise value, and therefore will constitute the main variables of the study. Distances considered will be kept above $20 \mathrm{~km}$. 


\section{Recycled Cement Paste}

A detailed mapping of the cement plants in France is available in [46], and enables a broad estimation of the mean cement plant distance in the area surrounding Paris, around $150 \mathrm{~km}$. Various distances, not smaller than this value, will be tested in the study.

Mode Of Transportation. Materials are mainly transported by roads with usual $38 \mathrm{t}$ lorries, whereas alternative transports such as inland waterway transport could be used. Road transportation represents $95 \%$ of total weight transported, which is explained by the fact that this mode of transportation fully comply with the constraints facing the building sector, which are (i) short transportation distances, (ii) a seasonal production cycle, (iii) temporary nature of construction site, (iv) small loads transported, and (v) reliable delivery schedules. For such small transportation distances, handling operations in unloading areas are far too significant for rail or waterway transports to compete. In addition railway stations or inland port be located near the quarry or the concrete batching plant are required, and this requirement matter-of-factly increases as natural aggregates are more and more sought in far-away quarries. Still, a closer look at regional specificities in France indicates that in Paris region, waterway is comparable to road in the importation of aggregates (5.3 Mt as against 8.5 Mt in 2002). The Administrative Region which mostly contributes to this importation is the neighbor Haute-Normandie Region (3 $\mathrm{Mt}$ ), its main inland port being at around $150 \mathrm{~km}$ from Paris along the Seine river.

Given these considerations, LCA simulations will also include the case of a waterway transportation of aggregates of $150 \mathrm{~km}$. This value will represent the upper bound considered, as the French professional Union in the field gave the estimation of $100 \mathrm{~km}$ for a waterway transportation averaged at the national scale.

\section{$\underline{\text { General Infrastructures }}$}

The emissions associated with the electrical consumption are modified in every sub-process of the global system to take into account the specificity of the French production mix of electricity, which strongly differs from the default Swiss one proposed in the Ecoinvent database. The share of electricity produced by nuclear plants is more important in France, and is made up for in the Swiss system by more hydrothermal and conventional thermic source [47].

\section{Impact Assessment (IA) and Discussion}

The system definition leads to various scenarios depending on the fragmentation technology used, the recycling rate of the cement paste, and the distance of transportation of the various materials involved. In what follows, two recycling rates of the RCP obtained by pulsed electrofragmentation have been considered, along with two distances of transportation for the concrete gravels to the WCTU and the aggregates leaving the WCTU to building construction $\left(\mathrm{D}_{4}\right.$ and $\mathrm{D}_{7}$ ), see Table 7 . The other transportation distances are not modified and are respectively $\mathrm{D}_{1}=41$ $\mathrm{km}$ for raw materials, $\mathrm{D}_{2}=20$ and $\mathrm{D}_{3}=40 \mathrm{~km}$ for natural aggregates, $\mathrm{D}_{5}=150 \mathrm{~km}$ for RCP, and $\mathrm{D}_{6}=10 \mathrm{~km}$ for concrete gravels (see Table 7).

This set of parameters allows evaluating the sensitivity of the results to the location of the WCTU. Values of $\mathrm{D}_{4}$ and $\mathrm{D}_{7}=0$ would correspond to a WCTU close to the demolition/construction sites, a condition which is not always met in practice owing to the minimal space required for the WCTU operations. 
Table 8. Variables studied in the present paper.

\begin{tabular}{|c|c|c|c|}
\hline \multicolumn{2}{|c|}{ Transport } & \multirow{2}{*}{$\frac{\text { RCP rate }}{\mathrm{P}_{\mathrm{RCP}}^{\mathrm{ck}}}$} & \multirow[b]{2}{*}{ Case } \\
\hline $\begin{array}{c}\text { Recycled aggregates } \\
D_{7}(R A C)\end{array}$ & $\begin{array}{l}\text { Concrete gravels } \\
D_{4}(R A C / R G E)\end{array}$ & & \\
\hline \multirow{4}{*}{$20 \mathrm{~km}$} & \multirow{2}{*}{$20 \mathrm{~km}$} & 0.340 & 1 \\
\hline & & 0.277 & 2 \\
\hline & \multirow{2}{*}{$100 \mathrm{~km}$} & 0.340 & 3 \\
\hline & & 0.277 & 4 \\
\hline \multirow{4}{*}{$100 \mathrm{~km}$} & \multirow{2}{*}{$20 \mathrm{~km}$} & 0.340 & 5 \\
\hline & & 0.277 & 6 \\
\hline & \multirow{2}{*}{$100 \mathrm{~km}$} & 0.340 & 7 \\
\hline & & 0.277 & 8 \\
\hline
\end{tabular}

Results for the environmental extra-cost brought by the alternative processing of reclaimed concrete are summarized Table 9.

Table 9. Balance of the environmental impacts between the current and the alternative scenario of processing $1 \mathrm{~kg}$ of reclaimed concrete

\begin{tabular}{|c|c|c|c|c|}
\hline Case & $\begin{array}{c}\text { Climate change } \\
\mathrm{kg} \mathrm{CO} 2 \mathrm{eq}\end{array}$ & $\begin{array}{c}\text { Terrestrial acidification } \\
\mathrm{kg} \mathrm{SO}_{2} \mathrm{eq}\end{array}$ & $\begin{array}{c}\text { Natural land transformation } \\
\mathrm{m}^{2}\end{array}$ & $\begin{array}{c}\text { Fossil depletion } \\
\mathrm{kg} \mathrm{oil} \mathrm{eq}\end{array}$ \\
\hline $\mathbf{1}$ & -1.04 & $-1.09 .10^{-2}$ & $-6.37 .10^{-6}$ & $-6.74 .10^{-3}$ \\
\hline $\mathbf{2}$ & -1.02 & $-1.08 .10^{-2}$ & $-6.25 .10^{-6}$ & $-3.52 .10^{-3}$ \\
\hline $\mathbf{3}$ & -1.03 & $-1.08 .10^{-2}$ & $-2.91 .10^{-6}$ & $-3.20 .10^{-3}$ \\
\hline $\mathbf{4}$ & -1.01 & $-1.07 .10^{-2}$ & $-2.79 .10^{-6}$ & $-1.32 .10^{-5}$ \\
\hline $\mathbf{5}$ & -1.05 & $-1.09 .10^{-2}$ & $-8.72 .10^{-6}$ & $-9.14 .10^{-3}$ \\
\hline $\mathbf{6}$ & -1.03 & $-1.09 .10^{-2}$ & $-1.04 .10^{-5}$ & $-7.79 .10^{-3}$ \\
\hline $\mathbf{7}$ & -1.04 & $-1.08 .10^{-2}$ & $-5.52 .10^{-5}$ & $-5.60 .10^{-3}$ \\
\hline $\mathbf{8}$ & -1.02 & $-1.08 .10^{-2}$ & $-6.97 .10^{-6}$ & $-4.25 .10^{-3}$ \\
\hline
\end{tabular}

All the impacts categories score to negative values, meaning that the proposed alternative processing allows reducing the environmental footprint of concrete wastes. The decrease is impressive concerning the avoided emissions in $\mathrm{CO} 2$, about $1 \mathrm{~kg}$ saved per $\mathrm{kg}$ of concrete wastes handled. The terrestrial acidification shows a constant value, apparently not affected by the various distances of transportation considered. Regarding the natural land transformation and the fossil depletion categories, it can be noted that the gain brought by the alternative processing scheme diminishes when $\mathrm{D}_{4}$ is increased (except for case 5) or when $\mathrm{D}_{7}$ is lowered. An important point is that the gain remains positive, whilst RAC is sent over $100 \mathrm{~km}$ to building construction sites.

To better understand the global results, the respective costs associated with the production processes (i) of clinker, (ii) of aggregates/gravels for embankments, and (iii) of aggregates for structural concretes are reported on Figure 3. These costs are expressed as differences between the impacts of the various modules presented in Figure 1: (3) - (5) gives the environmental cost to produce aggregates for embankments in the alternative scenario, (2) - (6) gives the costs for aggregates for structural concretes and (1) - (4) the cost for clinker manufacturing. The subtractions are weighted by the mass flows indicated (see Figure 1), to determine their respective significance in the global system.

The maximum allowed recycled cement paste in the clinker kiln $\left(\mathrm{P}_{\mathrm{RCP}}^{\mathrm{ck}}=0.340\right)$. 
Figure 3. Costs (in term of environmental impacts) of different processes in the global system described on Figure 1. The numbers on the horizontal axis correspond to the case described in Table 9. The content of RCP in the clinker kiln corresponds to the lowest value for CO2 emission $\left(\mathrm{P}_{\mathrm{RCP}}^{\mathrm{ck}}=0.34\right)$.

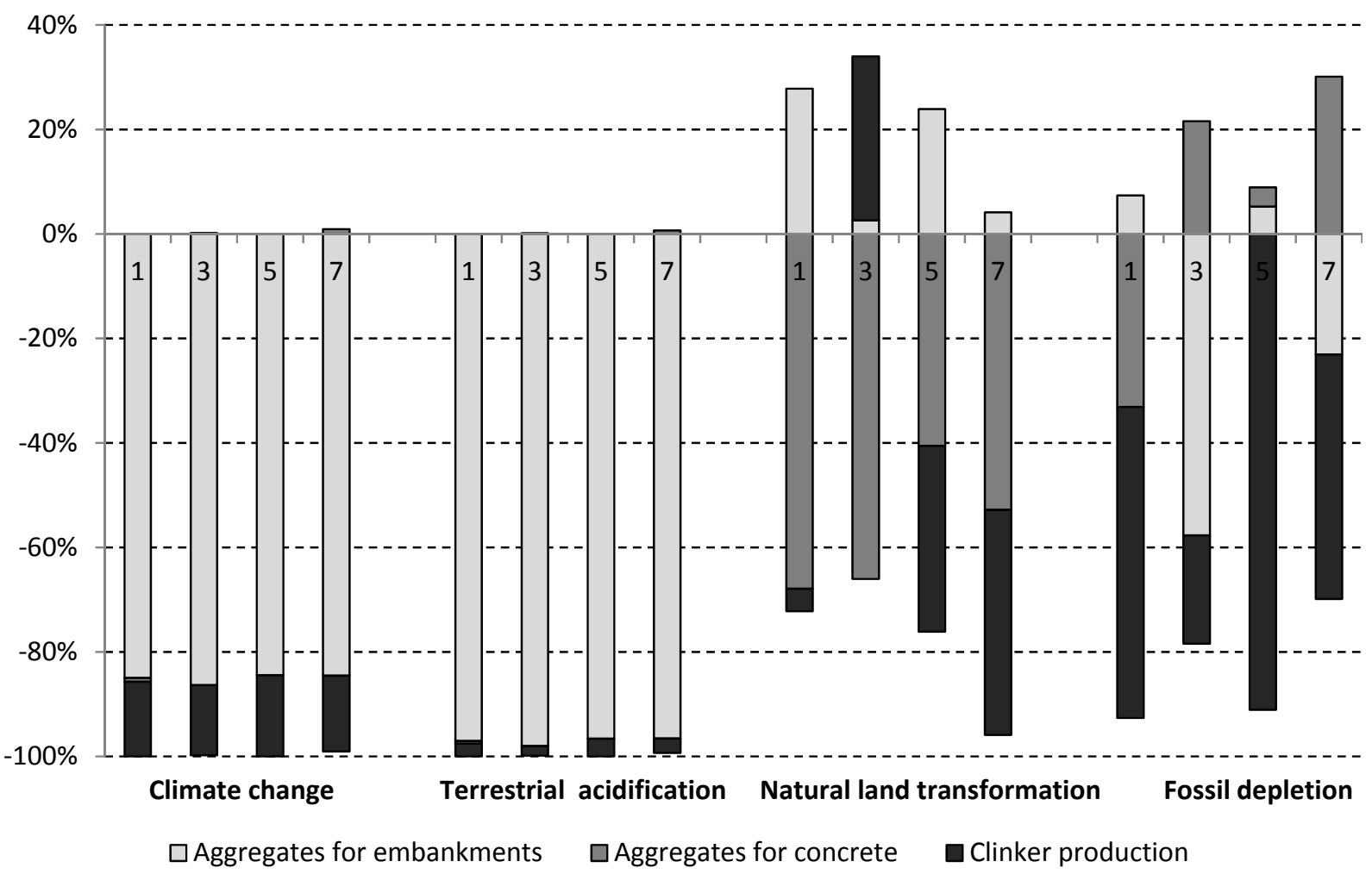

It can be seen from this figure that the production of aggregates for embankments is the main contributor to the decrease in climate change and terrestrial acidification. This is explained by the fact that crushing concrete is more energy-intensive than crushing solid rocks to recover aggregates, and therefore more fuel is consumed, resulting in higher $\left(\mathrm{CO}_{2}\right.$ and $\left.\mathrm{SOx}\right)$ emissions. The gain in natural land transformation is mainly accounted for by the production of aggregates for concrete, which is in agreement with the replacement of natural aggregates by aggregates from concrete. Similarly, the positive cost to produce aggregates for embankments (case 1) comes from the fact that gravels initially obtained from concrete wastes and now diverted to building concretes have to be found in natural quarries. This cost seems to decrease for case 3 and 7, which corresponds to $\mathrm{D}_{4}=100 \mathrm{~km}$. This is ascribed to the fact that, in ReCiPe Midpoint, an increase in the distance of transportation indirectly results in a higher occupation of natural land by road. Regarding fossil depletion, an important gain seems to accompany the alternative process. This is partly due to the feeding of the clinker kiln with less carbonated materials, requiring less amount of combustible to obtain the free lime. The production of aggregates for concrete depletes more fossil fuel in cases 3,5 and 7, which is explained by the distances of transportation of gravels to the WCTU or of RAC to building sites. The difference (3) - (5) reflects the same trend by becoming positive when the distance of transportation of concrete wastes to the crusher is $100 \mathrm{~km}$.

These preliminary results establish links between potential environmental gains in an alternative processing of concrete wastes and the various distances of transportations that intervene. Future work will therefore be conducted to investigate these links. 


\section{References}

1. D. Chisholm, "Best practice guide for the use of RA in new concretes" (CCANZ technical report TR14, ISSN 1171-4204, 2011).

2. S. Marinkovic et al., "Comparative environmental assessment of natural and recycled aggregate concrete," Waste Management, 30 (2010), 2255 - 2264

3. T.C. Hansen and H. Narud, "Strength of recycled concrete made from crushed concrete coarse aggregate," Concrete International, 5 (1983), 79 - 83.

4. C.S. Poon et al., "Influence of moisture states of natural and recycled aggregates on the slump and compressive strength of concrete," Cem. Concrete Research, 34 (2004), 31 - 36.

5. M. Bauchard, "Utilisation en technique routière de granulats provenant du concassage de béton de démolition," Bull. liaison Labo P. et Ch., 134 (1984), 53 - 57.

6. Y. Dosho, "Development of a sustainable concrete waste recycling system - application of recycled aggregate concrete produced by aggregate replacing method," J. Advanced Concrete Tech., 5 (1) (2007), 27 - 42

7. Portland Cement Association, "Recycled aggregates for reinforced concrete?" Concrete Technology Today, 23(2) (2002).

8. V. Corinaldesi and G. Moriconi, "Influence of mineral additions on the performance of $100 \%$ recycled aggregate concrete," Con. Build. Mat., 23 (2009), 2869-2876.

9. M. Kikuchi, T. Mukai, and H. Koizumi, Demolition and reuse of concrete and masonry: reuse of demolition waste (London: Chapman and Hall, 1988), 595 - 604.

10. M. Abe, "Study on production of recycled aggregate by gravity concentration method," (1997). JCA Proceedings of Cement and Concrete, 51, (1997), 482 - 487.

11. Y. Sakasume et al., "Development for production technique on high quality recyclable aggregate. Part 4. Method of screw grinding" (Paper presented at the Annual Meeting Architectural Institute of Japan, 2002), A-1, 1027 - 1028.

12. Y. Kuroda and H. Hashida, "A closed-loop concrete on a construction site" (Paper presented at the International symposium on sustainable development of cement, concrete and concrete structures, Toronto, Canada, 2005), $667-683$.

13. M. Etxeberria et al., "Influence of amount of recycled coarse aggregate and production process on properties of recycled aggregate concrete," Cem. Concr. Res., 37 (2007), 735 - 742.

14. M. Tsujino et al., "Application of conventionally recycled coarse aggregate to concrete structure by surface modification treatment," J. Advanced Concrete Tech., 5 (2007), 13 - 25.

15. J.S. Damtofts et al., "Sustainable development and climate change initiatives," Cem Concr Res., 38 (2008), 115 - 127.

16. Clamens (2012) http://www.groupeclamens.org/recyclage-beton les_tarifs_du_recyclage. html? qs $=$ tarif.

17. S. Maeda et al., "Research on concrete aggregate collection technology by pulsed power discharge" (Paper presented at the $34^{\text {th }}$ Conference on Our World in Concrete \& Structures, Singapore, 2009 August $\left.16^{\text {th }}-18^{\text {th }}\right)$.

18. A. Braunschweig, S. Kytzia and S. Bischof, "Recycled concrete: environmentally beneficial over virgin concrete?" (Paper presented at LCM 2011 - Towards Life Cycle Sustainability Management, Berlin, 2011).

19. Y. Ishikawa, "Issues in LCA in the concrete industry," JLCA Newsletter, 7 (2009), 13 - 16.

20. SETAC, Guidelines for life-cycle assessment: a code of practice (Society of Environmental Toxicology and Chemistry Press, Pensacola, FL, 1993).

21. N. Lippiat and F.Bourgeois, "Investigation of microwave-assisted concrete recycling using single-particle testing," Min. Eng., 21 (2012), 71 - 81. 
22. ISO (International Organization for Standardization) 14040. Environmental Management (1997). Life Cycle Assessment. Part I. Principles and Framework, Geneva, CH.

23. A. Tillman, T. Ekvall, H. Baumann, "Choice of system boundaries in life cycle assessment," J. Clean. Prod., 2 (1994), 21 - 29.

24. H. Udo de Haes et al., Life-cycle impact assessment: striving towards best practice (Pensacola, FL: SETAC Books, 2002)

25. D.N. Huntziger and T.D. Eatmon, "A life-cycle assessment of Portland cement manufacturing: comparing the traditional process with alternative technologies," J. Clean Prod., 17 (2009), $668-675$.

26. J.W. Owens, "Life -Cycle Assessment - Constraints on moving from Inventory to Impact Assessment," J. Ind. Ecol., 1 (1997), 37 - 49.

27. M. Goedkoop et al., "ReCiPe 2008 - a life cycle impact assessment method which comprises harmonized category indicators at the midpoint and the endpoint level. First edition", (http://www.leidenuniv.nl/cml/ssp/publications/recipe_characterisation.pdf).

28. C. Chen et al., "Environmental impact of cement production: detail of the different processes and cement plant variability evaluation," J. Clean Prod., 18 (2010), 478 - 485.

29. S. Solomon et al., Climate change 2007. The physical science basics. Contribution of Working Group I to the Fourth Assessment Report of the Intergovernmental Panel on Climate Change (Cambridge: Cambridge University Press, 2007).

30. B. Von Bahr et al., "Experiences of environmental performance evaluation in the cement industry. Data quality of environmental performance indicators as a limiting factor for benchmarking and rating," J. Clean Prod., 11 (2003), 713 - 725.

31. S. Guignot et al., "Development of an innovative technique for demolition concrete upcycling: a response to mitigate GHG's emissions and natural resources depletion" (Paper presented at the XXVI International Mineral Processing Congress - IMPC 2012, New Delhi, India, 2012).

32. C.W. Moore, "Chemical control of Portland cement clinker," Am. Ceram. Bull., 61 (1982), $511-515$.

33. R.H. Bogue, "Calculation of the compounds in Portland cement," Industrial and Engineering Chemistry, 1(4) (1929), 192 - 197.

34. H.F.W. Taylor, Cement chemistry (ICE Publishing, 1997).

35. G. Baudet, "Production de $\mathrm{CO} 2$ dans l'élaboration des ciments Portland. Bilans et possibilités de réduction des émissions" (Report 410, BRGM/French Geological Survey, 2004).

36. S.B. Marinkovic and I.S. Ignjatovic, Innovative materials and techniques in concrete construction (ACES Workshop). Chapter 7. Recycled Aggregate Concrete for structural use. An overview of Technologies, Properties and Applications (Michael N. Fardis Editor, Springer Science, 2010).

37. P. Van den Heede and N. De Belie, "Environmental impact and life cycle assessment (LCA) of traditional and 'green' concretes: Literature review and theoretical calculations," Cement Concrete Comp., 34 (2012), 431 - 442.

38. T. Martaud, "Evaluation environnementale de la production de granulats naturels en exploitation de carrières" (PhD Thesis, Orleans University, 2008).

39. U.M. Mroueh et al., Life cycle assessment of road construction (Finnra Reports 17/2000, Finnish National Road Administration, 1999).

40. Aggregate Industries, (Sustainability report, 2009). From: http://www.aggregate.com/ sustainability/. Accessed 11/05/12.

41. S. Sayagh, "Approche multicritères de l'utilisation de matériaux alternatifs dans les chaussées" (Ph.D Thesis, ENPC, 2007). 
42. INSEE - Service de Statistiques Nationales d'Entreprises (French National Statistics Office). La protection de l'environnement. Le transport des matériaux de construction. Accessed $11 / 05 / 12$.

43. G. Habert et al., "Development of a depletion indicator for natural resources used in concrete," Resources, conservation and recycling, 54 (2010), $364-376$.

44. ATILH - Association Technique des Industries des Liants Hydrauliques (2002). Module d'informations environnementales des ciments. From : http://www.infociments.fr/developpement -durable/construction-durable/icv-ciments

45. UNICEM "Etudes d'impact environnemental. Plus de complexité," Unicem Magazine, 760 (2012).

46. P. Lebret, "Inventaire des carrières d'approvisionnement des cimenteries en France métropolitaine” (Report BRGM/RP-56986-FR, BRGM/French Geological Survey, 2009).

47. Eurostat (2011). Electricity production and supply statistics. From: http://epp.eurostat.ec.europa.eu/statistics_explained/index.php/Electricity_production_and_suppl y_statistics. Accessed on 11/05/12. 